\title{
韓国密陽・三浪津邑における旧日本人居住地の形成と 旧鉄道官舎の変容に関する考察 \\ A STUDY ON FORMATION OF JAPANESE RESIDENTIAL DISTRICT AND TRANSFORMATION OF RAILROAD TIED RESIDENCE IN THE SAMRANGJIN OF MILYANG, KOREA
}

\author{
趙 聖 民*，朴 重 信**，金 泰 永***，布野修司**** \\ Sungmin CHO, ChungShin PARK, TaiYoung KIM \\ and Shuji FUNO
}

\begin{abstract}
This paper aims to clarify spatial formation of the previous Japanese residential district and transformation of railroad tied residence in the Samrangjin village of Milyang city (KOREA). Samrangjin Railroad tied Residence area was shaped on the grid lines along the railroad. In this research, we clarify formation process and spatial pattern of Samrangjin Railroad tied Residence. As the result of this study, we found that the characteristics of street construction and arrangement of Samrangjin Railroad tied Residence and transformation of living space by Korean living style.

Transformation of living space is caused firstly by change of the position of entrance. An appearance of 'MADANG' and living room are affected by the positional at change of entrance, and linked also with transformation of circulation. 'TATAMI room' is converted into 'ONDOL BANG' in general. And then, toilet, kitchen and living room are newly attached in succession. We can explain the process of expansion of interior and exterior space according to the main axis of three core spaces (Entrance - MADANG-Living Room). In this study we found out the composite formation of Japanese living style and Korean living style.
\end{abstract}

Keywords : Samrnangiin, Colonial City, Railroad Town, Railroad Tied Residence, Living Space 三浪津、植民都市、鉄道町、鉄道官舎、居住空間

\section{1. はじめに}

\section{1-1 研究の目的と意㧴}

本稿は、「日本植民地期における日本人によって形成された鉄道町 の形成とその変容に関する研究注 1」の一環として、密陽市三浪津邑

（図 1）松旨里の三浪津鉄道官舎地区を対象として、居住空間の構成 とその変容について考察することを目的としている。鉄道町は開港 場と共に韓半島における近代都市の起源として、韓国の都市形成に 大きな影響を与えてきた。前稿注 2 では、日本植民地期における三浪 津邑松旨里の都市形成と土地所有者変化を土地台帳を基にした分析 によって明らかにし、鉄道町の形成過程と、土地利用の変化につい て考察を行った。

本稿では、日本人によって建てられた日式住宅注 ${ }^{3}$ が、韓国人の居 住によってどのように変容してきたかを明らかにする。定型的な鉄 道官舎を対象とすることによって基本的な変容パターンを把握する のが大きな狙いである。

日本植民地期における日式住宅及び鉄道町に関する既往研究には、 李賢姫の「韓国における日式住宅の变遷とその影響に関する研究」注 $4 、$ Chae Gi-Byung, Kim TaiYoung の「鉄道建設における近代的都市構造
の形成に関する研究 注 $5 、 J u ~ U-I L 、$ Kim SangHo、Lee SangJung の「近 代化の過程で建立された晋州鉄 道官舎の平面類型に関する研究」 注 6 、Kim SuYoung、Park YoungHwan の「解放以前における鉄道官舎の 平面特性に関する研究」注7などが ある。以上の研究は鉄道町におけ る街区形態の

分類、官舎の 類型、変容後 鉄道官舎の形 態や用途に主 な焦点を当て ている。本稿 では、実測調 査とヒヤリン グを基に変容
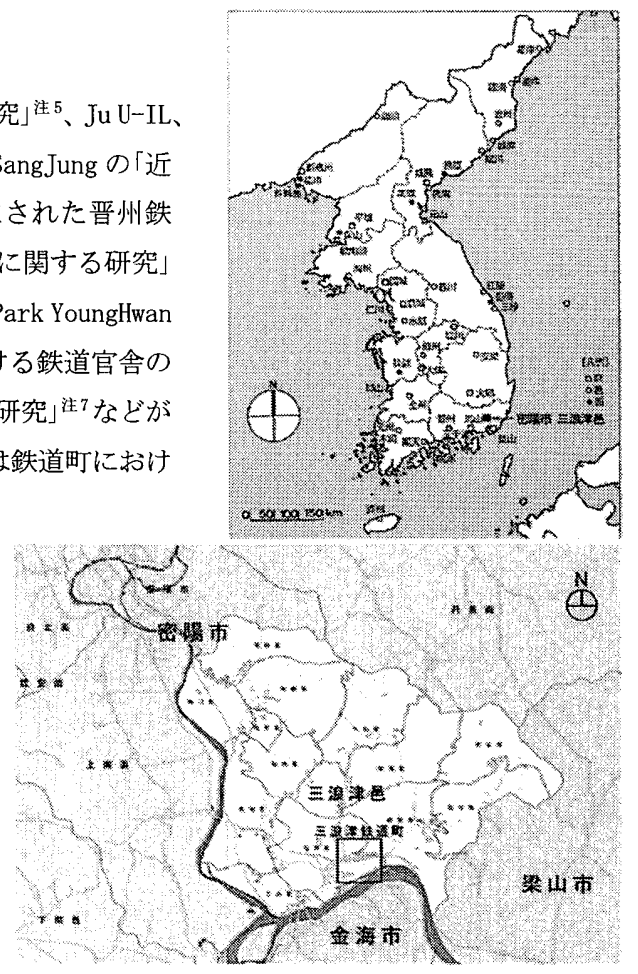

図 1 三浪津の位置と隣接都市
* 滋賀県立大学環境科学研究科 博士後期課程・環修

** 滋賀県立大学環境科学研究科 客員研究員・工博

*** 清洲大学校建築工学部 教授・志博

**** 滋賀県立大学環境科学研究科 教授. 工博
Graduate Student, University of Shiga Prefecture M. Env.

Researcher, University of Shiga Prefecture, Dr. Eng.

Prof., Dept. Architecture and Environmental Design, Cheongju University, Dr. Eng. Prof., Dept. University of Shiga Prefecture, Dr. Eng. 


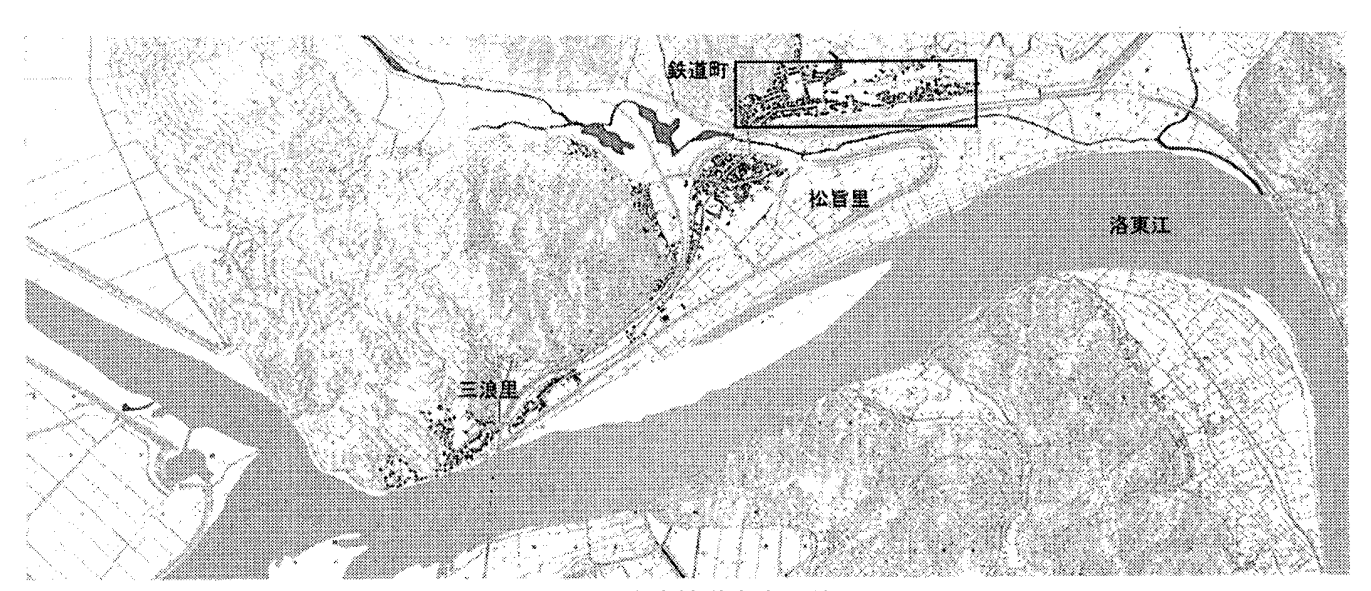

図 2 三浪津鉄道官舎の位置

本稿では三浪津鉄道官舎 地区に建てられている 6 ・ $7 \cdot 8$ 等級官舎を対象とし、 払下げ後の変容特性に集点 を当てる。この分析によっ て、韓日両国の居住文化の 差異及び地域性を解明する に当たって重要な手がかり を得られると考える。

\section{1-2 調查概要}

本稿は 4 次にわたる現地 調查を基としている。第 1 次調査 $(2004$ 年 3 月 25 日

の原因となる要素を中心に分析している。日式住宅の変容によって 表れる新たな空間と機能を明らかにすることを視点としている新た な三浪津での旧日本人町と旧鉄道官舎に関する文献は、他の鉄道町 と比べると非常に少ない。朝鮮総督府鉄道局出版の『朝鮮鉄道線路 案内』注 8 と朝鮮建築会出版の『朝鮮と建築』注 9 が重要な手がかりと なる。また、日本植民地期の都市計画に関する主要な文献は末尾に 示す通りである。

三浪津鉄道官舎が位置している松旨里は次のような特徴を持って いる(図 2)。

(1)洛東江辺に位置し、周辺地域の収穫物や資源などを水運と鉄道 で集積する交通の要所である。

(2)国鉄京釜線注 10 、慶全線注 11 の分岐点に立地する。

(3)駅前商店街や鉄道官舎など昔からの町並みが多く残されている。 部分的な変化はあるが、駅側商店街や鉄道官舎の全般的な部分 については当時の構造がそのまま残っている。駅前商店街は 2 階建ての町屋で、鉄道官舎は平屋で全て二戸一形式である。
-28日）注12では、現地確認と写真の撮影、そして地元大エへのヒヤ リング調查を行い、第 2 次調查（2005 年 8 月 2 日 - 10 日）注 13 では 地籍図、地形図、韓半島で建設された鉄道官舎の基本設計図につい ての資料収集を行い、三浪津鉄道官舎の実測調查を行った。第 3 次 調查 $(2006$ 年 2 月 25 日 - 28 日）注 14 では鉄道官舎地区の街区構造や 地形について調查を行った。また、駅前商店街を中心とした町並み 調査や各店舗の実測調查を行い、 42 件の日式住宅の情報を収集した。 第 4 次調查 $(2006$ 年 6 月 12 日 - 13 日）注 15 では鉄道官舎 34 戸の内 16 戸に対して精密実測調查を行った。さらに、居住空間の改増築な どに関するヒヤリング調査を同時に行い、居住空間の変容に関する 資料を収集した。

\section{2. 三浪津邑鉄道町の形成}

韓国における鉄道建設は、ソウルと仁川間を慗ぐ京仁線の敷設か ら始まる。京仁線は京仁鉄道株式会社によって 1897 年一 1900 年の 4 年間かけて建設された。それ以後、京釜線、京義線が次々と敷設さ れ、韓半島での新たな交通手段の時代が始まる主 ${ }^{16}$ 。京仁鉄道株式会

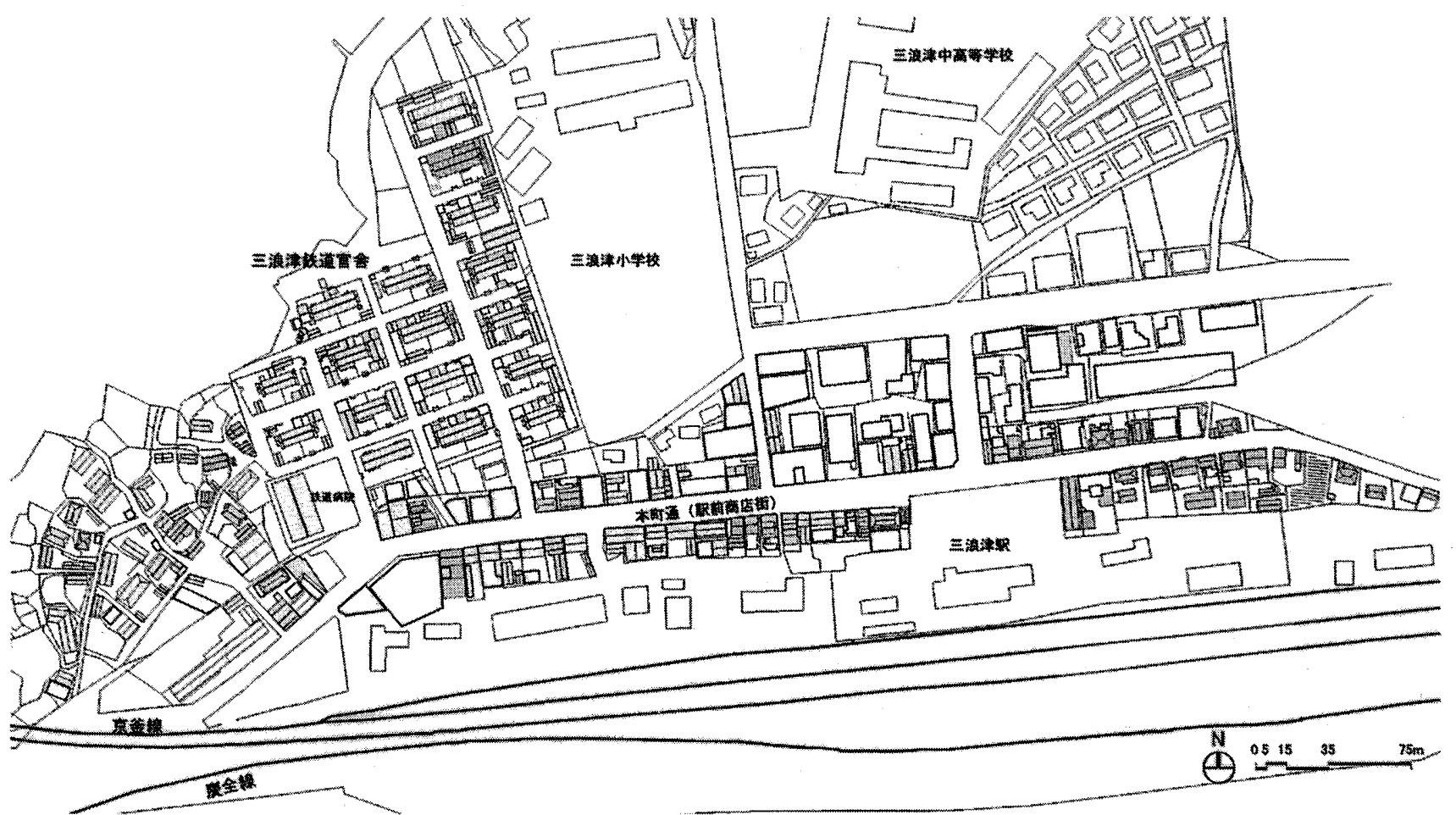

図 3 三浪津鉄道町の街区構造 
社は京釜鉄道株式会社の設立（1905 年）と共に同社に売買されるこ とになり、次いで京釜鉄道株式会社及び臨時軍用鉄道監部は 1906 年 に朝鮮総督府鉄道局の所属となった。

鉄道敷設と共に鉄道駅や鉄道官舎も上記の三つの系列に伴って建 設された。現在残されているほとんどの鉄道官舎は経営権が朝鮮総 督府鉄道局となった以後に鉄道局の標準設計図によって建てられた ものである(図 3)。

三浪津邑は、密陽市の南端に位置し、金海 (キムへ) と梁山（ヤン サン）と境界を接している。周辺地域からの租税を集めた洛東江周 辺の水運を利用する拠点となった上部・下部村と、両班階層が集中 的に居住していた安台里以外の大半の自然集落は賎民地域で、洛東 江から離れた山奥側に集中的に村を形成した。この三浪津邑が注目 され出したのは、豊臣秀吉の朝鮮出兵注 17 (壬辰位乱、丁西再乱) か らであり主 18 、洛東江の水運と共に軍事的な要所となった。

以上のように嶺南地域注 19 の国防や物流の要地として知られてき た三浪津邑は、近代に入って、鉄道の敷設と共に新たな展開を遂げ る。1905 年に敷設された国鉄京釜線と 1906 年に敷設された臨時軍 用線である慶全線の分岐点となることで近代的な交通要地として注 目されるのである。

1911 年出版された朝鮮総督府鉄道局の『朝鮮鉄道線路案内』によ ると、三浪津邑に居住している日本人は 603 人、戸数 179 戸となっ ている。三浪津邑へ初めて日本人が入植したのは 1910 年頃とされる
が注 20、鉄道と洛東江が持つ陸・水運の利点から見ると、それ以前か ら日本人の入植が始まっていたと考えられる。前稿で明らかにした ように一筆あたりの宅地の平均面積は、日本人 $325.6 \mathrm{~m}^{2}$ 、韓国人 146.6 $\mathrm{m}^{2}$ 、日本人一戸当たりの居住人数は 3.37 人、韓国人は 4.67 人である。 生活水準は非常に差があった注21。松旨里には、三浪津邑役場、三浪 津警察署、憲兵隊、三浪津郵便所・電信取扱所、三浪津尋常高等小 学校、本願寺布教所、韓国與業株式会社三浪津出張所、農業共同組 合三浪津支店など主な行政、金融、教育、産業施設など主な施設が 設置され三浪津邑の行政、経済の中心地となった。松旨里の本格的 な都市化は 1925 年から開始された鉄道官舎と駅前商店街の建設が大 きなきっかけとなっている。三浪津邑松旨里は韓国の他の著名な鉄 道町と比較して、町の規模（人口、産業など）は極めて小さいが、 現在も洛東江や鉄道の分岐点という水陸交通の利点を生かした、嶺 南地域の流通、産業の中心である。

\section{3. 鉄道官舎の構成}

三浪津鉄道町は、駅を中心として北側に駅前商店街や駅広場が位 置し、駅から約 $200 \mathrm{~m}$ 離れている北西側には格子状の街路を持つ鉄道 官舎が建設されている。

\section{3-1＼cjkstart官舎の構成と街路体系}

三浪津鉄道官舎は鉄道線路に直交する主道路を持つ格子状道路網 の東西 $230 \mathrm{~m}$ 、南北 $260 \mathrm{~m}$ の敷地に、1905 年の国鉄京釜線の敷設後、 1927 年から 1945 年までの 18 年間で 17 棟 34 戸が建設された。また、

\section{表 1 三浪津鉄道官舍の概要}

\begin{tabular}{|c|c|c|c|c|}
\hline & 所在地 & 啭年 & 等勅 & 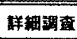 \\
\hline (1) & 松宣里 166-? 娄地 & 1940年 & 6 被 & \\
\hline (2) & 松旨里 166-6 首地 & 1940年 & 6 級 & K6a1 \\
\hline (3) & 松昌里 168-10 散地 & 1945年 & 7級 A型 & K7a1 \\
\hline (4) & 松志里 166-11 委垉 & 1940年 & 7 級明型 & \\
\hline (5) & 松氮墨 166-12 地 & 1940 年 & 7級A整 & \\
\hline (6) & 松旨里166-13槒地 & 1927 年 & 7級A整 & \\
\hline (2) & 松宣黑 168-18 部地 & 1940 年 & 7 級契 & K7a3 \\
\hline (8) & 松宣黑 $168-19$ 粪地 & 1940年 & ?級型 & $\mathrm{K} 7 \mathrm{a} 2$ \\
\hline (9) & 松旨里 166-21 畨地 & 1940 年 & 7級和型 & \\
\hline (10) & 昖旨里 166-22 形地 & 1940年 & 7 級慜 & \\
\hline (11) & 昖旨里 316-6香地 & 1940 年 & 級慜 & \\
\hline (12) & 昖皆里 316-7番地 & 1938 年 & 7稌型 & K7a4 \\
\hline (13) & 松旨里316-11 委地 & 1938 年 & 7 級 B整 & \\
\hline (14) & 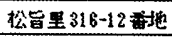 & 1940年 & 7 級 B & K7b1 \\
\hline (15) & 松旨黑 318-13 覓地 & 1938 年 & 7級B型 & $\mathrm{K} 7 \mathrm{~b} 2$ \\
\hline (16) & 松察里 316-14 歌地 & 1940年 & ?級B型 & \\
\hline (1) & 松皃里 $166-24$ 地 & 1940 年 & 86 & $\mathrm{~K} 8 \mathrm{a} 3$ \\
\hline (18) & 松旨里 186 -25 糔地 & 1940 年 & 8级 & \\
\hline (19) & 昖旨里 186-15 部地 & 1940年 & 8 级 & \\
\hline (20) & 松旨里 $166-18$ 采㢮 & 1940 年 & 8級 & K8a5 \\
\hline (21) & 松旨里 185-6臬地 & 1948年 & 8 級 & K8a6 \\
\hline (22) & 伀旨里 316-3羙地 & 1940 年 & 8 级 & \\
\hline (23) & 昖旨里 185-9番地 & 1940 年 & 8 級 & $K 8 a 8$ \\
\hline (24) & 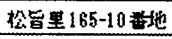 & 1940 年 & 8 級 & K8a7 \\
\hline (25) & 松旨里 $165-12$ 要地 & 1940年 & 8 級 & \\
\hline (26) & 松旨里165-13 再地 & 1940 年 & 8 级 & \\
\hline (2) & 昖皆里 318-1 娄地 & 1940 年 & 8 級 & K8a9 \\
\hline (28) & 松旨里 316 -10粦地 & 1943 年 & 8 級 & $K 8 a 4$ \\
\hline (29) & 松旨里 318-3番地 & 1940 年 & 8 級 & \\
\hline (30) & 松宣里 316-16 畨地 & 1940 年 & 8級 & \\
\hline (31) & 彸葛里 $166-28$ 新地 & 1940 年 & 8 級 & \\
\hline (32) & 松宣里 166-2? 椅地 & 1930年 & 8 級 & \\
\hline (33) & 松旨里 318-8雍地 & 1345 年 & 8 級 & $\mathrm{K} 8 \mathrm{a} 2$ \\
\hline (34) & 松旨里318-17芧地 & 1940 年 & 8 級 & K8a1 \\
\hline
\end{tabular}

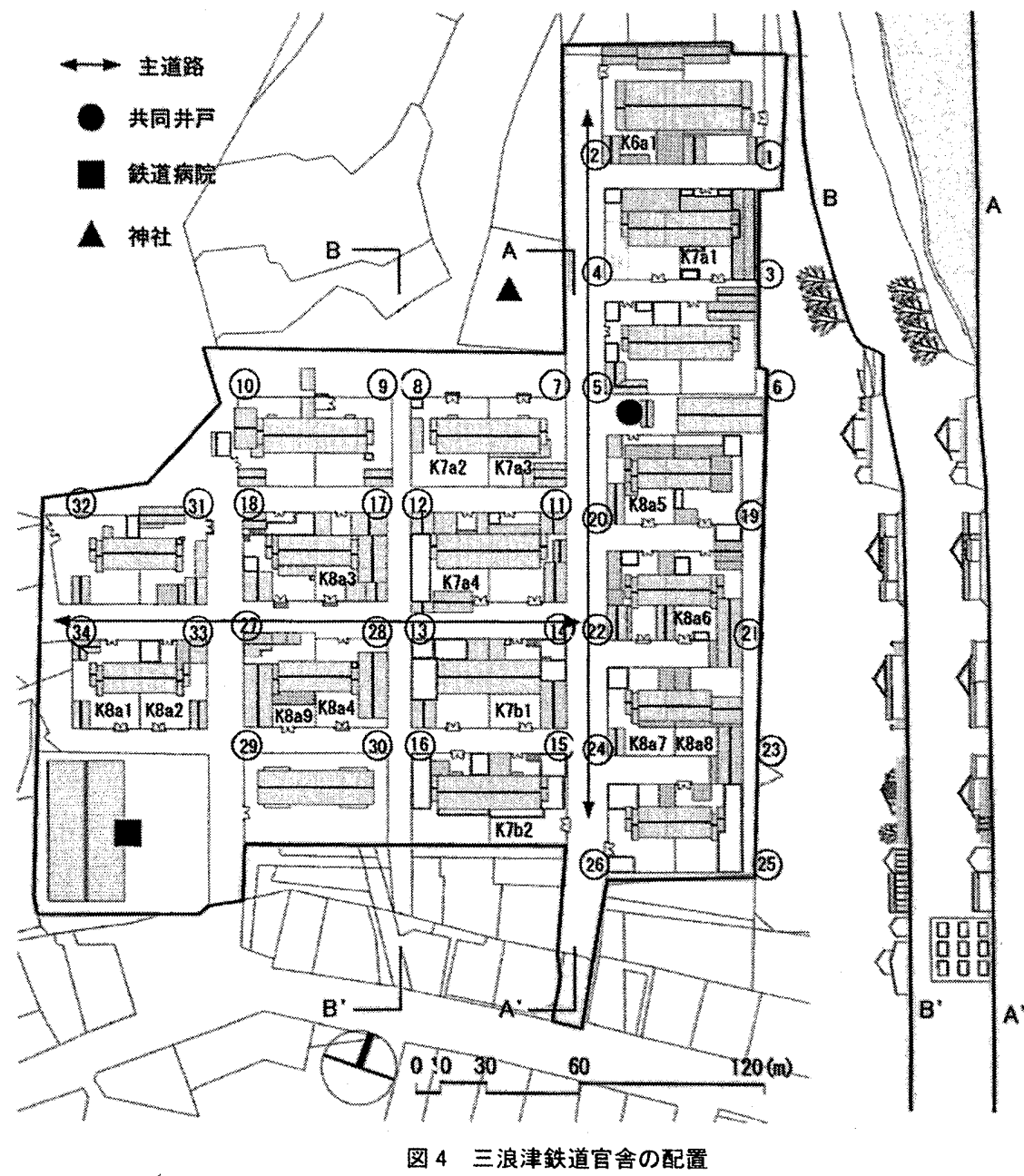


別に鉄道病院 1 棟が建てられた。 34 戸の建設年、等級は表 1 に示す 通りである。

全体構成は南北方向の斜面に沿って標高の高い北側に上級官舎、 南側と外側に下級官舎が配置され、下級官舎が上級官舎を囲む形と なっている。平均幅 $7 \mathrm{~m}$ の主道路（南北・東西）と、平均幅 $5 \mathrm{~m}$ の副 道路が格子状に地区全体を構成している。また、丘の一部を切り取 つて造成した敷地であるため道路と各敷地の段差に石垣を築き、生 垣の塀を設けている。敷地と道路の境界に溝を掘り生活用水や雨水 を流す下水路としていた。こうした日本植民地期当時の街区構造と 街路体系は、1970 年代半ばから実施された当地区の上下水道工事に よって溝が埋められ、道路幅が拡張され、生垣の塀がコンクリート ブロック塀に変わるなど部分的な変更がある以外、ほとんど変わっ ていない。

\section{3-2 鉄道官舎の類型と配置}

鉄道官舎地区は、鉄道官舎、鉄道病院、共同井戸、そして神社で 構成されている。鉄道官舎は 6 等級、 7 等級 $A 、 7$ 等級 B、 8 等級官 舎の四つのタイプで構成されている。各タイプの間取りを図 5 に示 す。具体的には北東端に駅長と補線事務所長の 6 等級官舎、その南 側 2 列と北中央部に 7 等級 $\mathrm{A}$ 、南中央部に 7 等級 $\mathrm{B}$ 、そして東西の 外側と南端の部分が最下級である 8 等級官舎が配置されている。全 ての等級の出入口や玄関は全て北側に位置し、南側に庭が置かれて いた。こうした出入口の配置は払下げ以後、韓国人の生活様式によ って大きく変化することとなった。

主な施設として、中央東に共同井戸が置かれており、鉄道官舎地 区唯一のコミュニティ施設として位置づけられている。上下水道が 完備していなかった 1970 年代半ばまでは生活用水は井戸に依存し、 飲料水は週 3 回程度鉄道局から共給されていた。現在も洗濯や洗車 などは井戸で行われおり、井戸端会議などコミュニティ施設として その役割を果たしている。

鉄道病院は 1989 年撤去され、現在はスーパーマーケットに建て替 えられている。撤去の前までは三浪津邑の松旨里、三浪里、検世里 にある唯一の病院として駅員は勿論地域住民にとって最も重要な医 療施設であった。そして、宗教施設として、鉄道官舎や駅前商店街 の居住者によって建てられた神社が当地区の北側の低い丘に位置し ている。この神社は解放後撤去され、その跡地に新たに円仏教注22 の 寺が建てられている。神社へ登っていく階段の跡、神社本棟があっ た跡地、そして背面にあった竹林が残されている。

\section{4. 鉄道官舎の変容}

上述のように三浪津鉄道官舎は、建設当時、全ての出入口や玄関 が北側に面しており、南側に庭が置かれていた。また、格子状の道
路に囲まれ、丘の斜面の高低差のために築かれた石垣の上に敷地が 設定されていることで敷地の拡張などの変更が難しくなっている。

\section{4-1 出入口の変化}

韓国の伝統的住居においては基本的に南入口を重視している。す なわち、寒い冬場に北側からの綮しい風を遮断するため、また、敷 地と面している畑などに慗げる勝手口の利用のため、さらに、法事 の時先祖の霊が通る死者の通路と認識されているため北側を除いた 方向に出入口を設けるのが一般的である。

1970 年代初期に行われた払下げ以後、官舎 34 戸の内、立地的な理 由で変更を行ってない官舎 $6 、 7 、 8 、 9 、 25$ を除いた 29 戸が出入口 の位置を変更している。その内、新築された官舎 29 、官舎 30 を除く 27 戸の内南側に 20 戸、東側に 3 戸、西側に 4 戸が出入口を変更して いる(図6)。

出入口の位置の変化は、内部空間の動線を変化させ、住居の内外 部空間の機能変化に慗る。その中で最も目立つのが庭のマダンへの 転用である。北出入口の位置の変化により庭として使われていた空 間がマダンへと転化し、それにより居住空間の動線に大きな変化が 起き、その結果、内部空間の構成や機能変更にも影響を与えている。 4-2 庭のマダンへの転用

'マダン' は、韓国の伝統的民家においては、動線の溜まり場、 作業場、葬式、祝賀会などの儀礼に使われる多目的な外部空間とし て最も重要な役割を果たしてきた。特に、外部道路から始まる進入 動線を各室に分散させる動線をコントロールする機能を持つ空間で ある。

34 戸の内 27 戸でマダンへの転用が確認された。庭の機能を維持し ている 7 戸（官舎 $1 、 6 、 7 、 8 、 9 、 10 、 25 ）$ の内 5 戸（官舎 $6 、 7 、 8 、$ 9、25）は北側出 入口、2 戸は東 （官舎 1）と西 （官舎 10）に出 入口が位置して いる。マダンへ の転用により官 舎本棟の南中央 部に玄関やリビ ングが設けられ、 道路一玄関一廊 下一各室/庭か ら道路一大門一 マダンーリビン

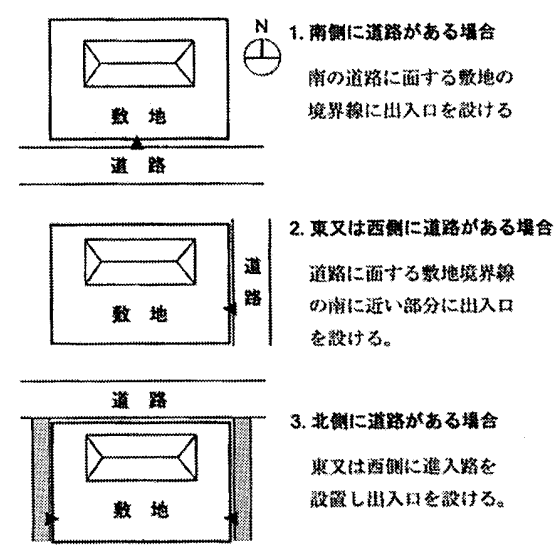

図 6 韓国居住空間の出入口配置の仕組み

\begin{tabular}{|c|c|c|c|c|}
\hline 区分 & 6 等級宣㝜 & 7等級A宦念 & 7 等級B官蕃 & 8筙报菅含 \\
\hline 平面图 & $X+\sqrt{n})$ & $M-]^{-1}-M$ & $-\sqrt{-1}-x$ & $\frac{036}{\sqrt{1+1}}$ \\
\hline & $E$ & $N-4=5$ & $2-$ & \\
\hline 居住㨋 & 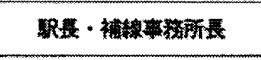 & 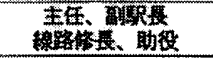 & 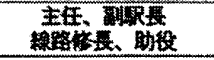 & その他の下赤螴 \\
\hline 建窥面楼 & 25.8 城 & 226 郸 & 19 靯 & 13.7 郸 \\
\hline 教地面䖽 & $468 \mathrm{~m}(26 \mathrm{~m} \times 18 \mathrm{~m})$ & $325 \mathrm{~m}(25 \mathrm{~m} \times 13 \mathrm{~m})$ & $325 \mathrm{~m}^{\circ}(25 \mathrm{~m} \times 13 \mathrm{~m})$ & $299 \mathrm{~m}^{\prime}(23 \mathrm{~m} \times 13 \mathrm{~m})$ \\
\hline 權造 & 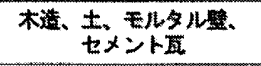 & 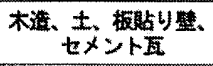 & 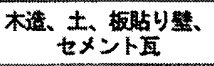 & 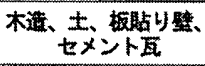 \\
\hline
\end{tabular}

図 5 三浪津鉄道官舎の標準設計図
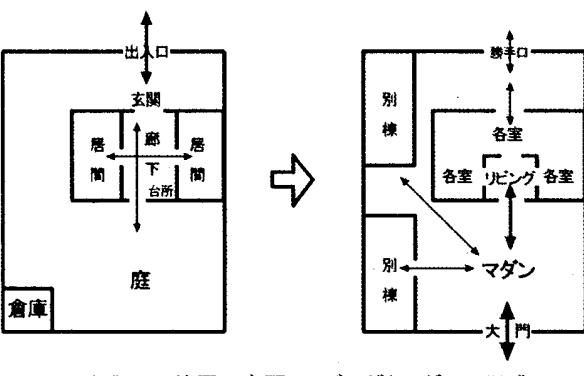

出入口の位置の変更・リビングとマダンの形成 台所、トイのの位置の变更・別楝の增筑

図 7 マダン形成と動線の変化 
グー各室へと動線の変化が起きている（図 7)。

三浪津鉄道官舎では、以上の出入口の位置変更と庭のマダンへの 転用が居住空間変容の最も大きな変化となっている。その特徴は以 下のようである。(1)台所の居住棟北側への移動が多い。(2)便所は室 内から室外と変わった後、上下水道が完備された後再び室内に入っ たものが多い。(3)南北道路に面して別棟が増築される。(4)本棟の南 側にリビング空間、北側に収納空間の拡張パターンが多い。
4-3 リビング（コシル）の出現

以下、詳細調査を行った 16 戸を中心に見てみたい。その変容の全 体概要は表 2 及び図 8 に示している。

16 戸に対する詳細調査で、北側に出入口がある官舎 7、8、以外の 14 件の住宅で庭がマダンへと転用が行われ、官舎 $2 、 34$ 以外の 14 件 でリビングが設けられている。

マダンは主に敷地に南側の庭が転用されているが、使い方によっ

表 2 増改築の現状

\begin{tabular}{|c|c|c|c|c|c|c|c|c|c|c|c|c|c|}
\hline 20 & 大篎 & |ル゙ンング & 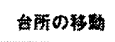 & 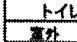 & 5 & 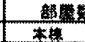 & 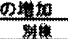 & 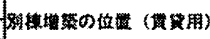 & 元の入口の闌道 & ジャ゙ンドックテ & |マダン or 噟 & 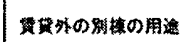 & 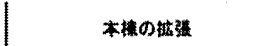 \\
\hline min & 区. & & 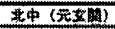 & ten & & & 2 & 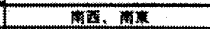 & & $\pi$ & $M$ & 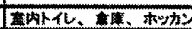 & \\
\hline 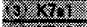 & an & 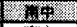 & 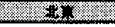 & 201 & at & 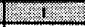 & 27 & 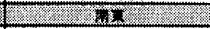 & $497 a^{2}$ & & in & 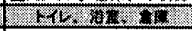 & 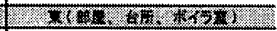 \\
\hline Lna? & 莣 & 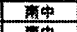 & & 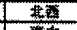 & & & & & 太응 & 7 & $\mathrm{~N}$ & 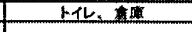 & 17ctron \\
\hline 10203 & \pm & 䨗中 & & 为中 & & & 2 & 表基 & $\mathrm{Xm}$ & a & M & & 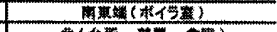 \\
\hline 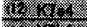 & 표 & 鄗 & 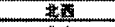 & 迺 & & & 2 & 重金蹎 & 60 & 柆 & a & 酷 & 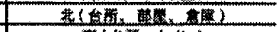 \\
\hline 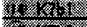 & 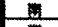 & 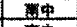 & ath & 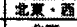 & 至电 & & 2 & pex & 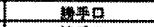 & 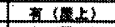 & $M$ & F, 的 & 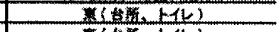 \\
\hline 10.783. & 咅 & 毠中 & 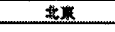 & a & 昰 & & & & 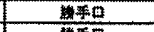 & $\pi(8 x)$ & $M$ & 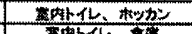 & 具( \\
\hline 9. 641 & 恶 & & & 25 & 迸要 & & 3 & 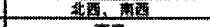 & E年D & 全 & $M$ & 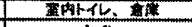 & \\
\hline 93.1642 & 恶 & 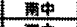 & 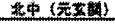 & 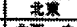 & 武票 & 1 & 1 & 帮羔 & 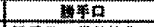 & 3. & $M$ & Fr & 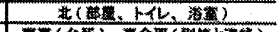 \\
\hline DIX & 兹 & Fi & & Et: & & \pm & 3 & 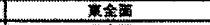 & 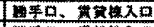 & 童 & $\mathbf{M}$ & 政 & 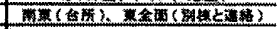 \\
\hline S & 裏 & क & 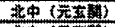 & t梠 & 프 & $i$ & 3 & 要全面 & 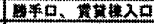 & 吾 & $x$ & & 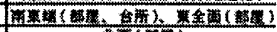 \\
\hline 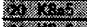 & 舟 & 丽串 & 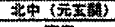 & 茫菭 & ति & 1 & 1 & 需然 & Bffo & 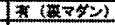 & $m$ & 茎AFAL & 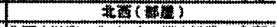 \\
\hline 1936 & 盟 & 需中 & 骨 & 就基 & 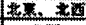 & 1 & 3 & 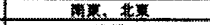 & 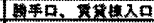 & 㽦 & 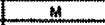 & & 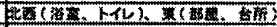 \\
\hline 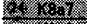 & F & 雨 & 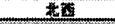 & 远育 & 地然 & 1 & 1 & 楼 & 青船 & $\neq(\mathrm{E} D)$ & $M$ & 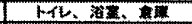 & 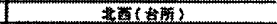 \\
\hline M.ras & 5 & 91 & The & 23 & II & 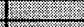 & 3. & 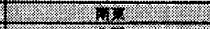 & The & - & a. & -14. II & 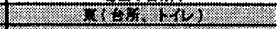 \\
\hline 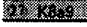 & (4) & Der & $254(2 x)$ & ma & & 81 & & (12) & $\sqrt{25}$ & 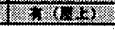 & $\mathrm{M}$ & Mra. Whit ne & Wrene en ares \\
\hline
\end{tabular}

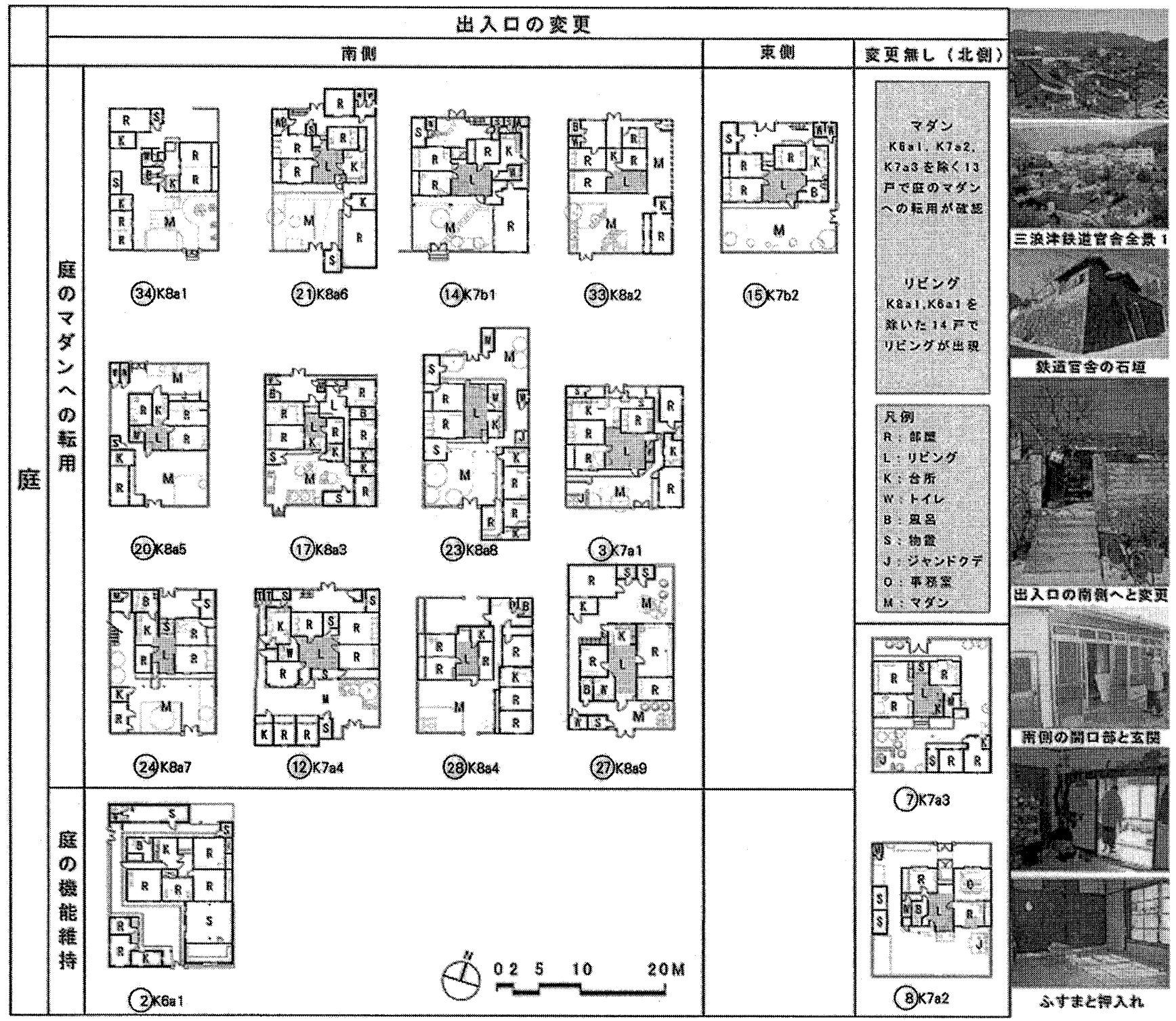

図 8 居住空間変容形態による類型 
て敷地の北側にディッマダン注 23 、東西の道路側にも小さいマダンが 設けられた場合もある。主にディッマダンと東西の道路側にも小さ いマダンはジャントッテなどの台所関係の物置が多いため台所と隣 接している場合が多い。こうしたディッマダンと東西の道路側にも 小さいマダンを利用しているのは、官舎 $15 、 20 、 23 、 24 、 27 、 30 、$ 33 の 6 軒である。

リビングは廊下を改造し、居住棟の中央部南側に設けられている。 マダンから入った動線はリビングに繋がり、リビングから各室へ繋 がる動線となる。ソファが置いている立式リビングもあるが大半は 座敷リビングである。特に、夏の暑い時に家族が食事する場合は風 通りがいいリビングを使うところが多く、官舎 $3 、 12 、 15 、 23 、 24 、$ 27 ではりビングを広く拡張し法事を行う空間としても使われている。 以上のような使い型は、半内部空間である韓国の大庁マル注 24 が内部 化したものであるともいえる。こうしたマダンとリビングは、動線 の集結・分散の起点となり、多機能を持つ居住空間の内外部として 各室を連結する役割を果たしている。

\section{4-4 増改築}

三浪津鉄道官舎での増築は、出入口の変更があった場合に最も激 しく起き、その中でも南側に大門を設けた場合に賃貸用の別棟が新 築されるなど変化の程度が大きくなっている。増築の特徵は、前述 したように、斜面を削り、石垣を築いて造成した道路と敷地の間に 様々な段差があるため、合筆による敷地の拡張が非常に難しいが、 官舎 $1 、 2 、 10 、 12 、 32$ で一部拡張されている。官舎 1 棟に付き所有 者が異なり、2 戸の住宅が棟を共有しているため片方だけの撒去が非 常に難しく、增改筑は内部改造と機能の追加に伴う内部空間の拡張 という建築行為が中心となっている。その増築の様子は図 9 に示し ているようにマダンとリビングが動線の主な役割を分担した上で各 室に連絡している。具体的な一例を図 11 に示す。

増築は、北側に台所、便所、室内倉庫 (家電製品、食器、法事用品
などの小型のもの)、ジャンドッデ注 ${ }^{25}$ ホッカン注 26 など、南側に賃貸棟、 倉庫(農機具などの大型のもの)が 付加されるのが一般的である。そし て隣地境界線側より道路と面して いる外側への東西部に増築が多く 行われている。

\section{4-5 内部空間の変化}

前述したように、三浪津鉄道官舎 は二戸一型で二つの住宅が構造体

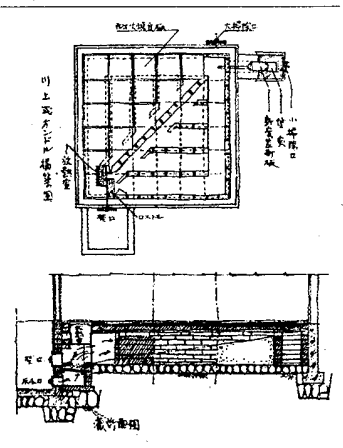

図 10 村岡式床暖房
を共有しているため全体の改造は難しい、一般的に用途や位置の変 化による変容が数多く見られる。中でも便所と台所の位置の変化が 数多く見られる。また、1940 年代の村岡式、川上式、大野式の床暖 房導入注 27 にって一部の畳部屋が無くなるなど、床の形式が変化し ている(図 10)。さらに 1970 年代の床暖房形式の変化によりボイラ 一室が追加される。主屋における部屋の増築は官舎 17、20、21、24、 27、28、33 で一室追加されるなど住戸面積の小さい 8 等級官舎で見 られる。その他、別棟を建てることで不足の部屋をすること追加が 一般的に見られる。面積に関わらず主屋の南側に位置している部屋 は韓国の夫婦部屋であるアンバン注 28 又はクンバン注 29 と呼ばれるよ うになっている。

居住者へのヒヤリング調查によると 収納空間が多い。襖を取り 外すと部屋が広く使えるため生活しやすい。’、空が多いため冬は寒 いが、夏は換気性がよくて涼しくて湿気も溜まらない。、という評 価が多く、構造体、襖、押入などの構成は変化させず使用している。 計画の段階から換気と通気を綿密に考慮して建設された鉄道官舎は、 多湿地域である三浪津邑の気候条件に適切であったと判断される。
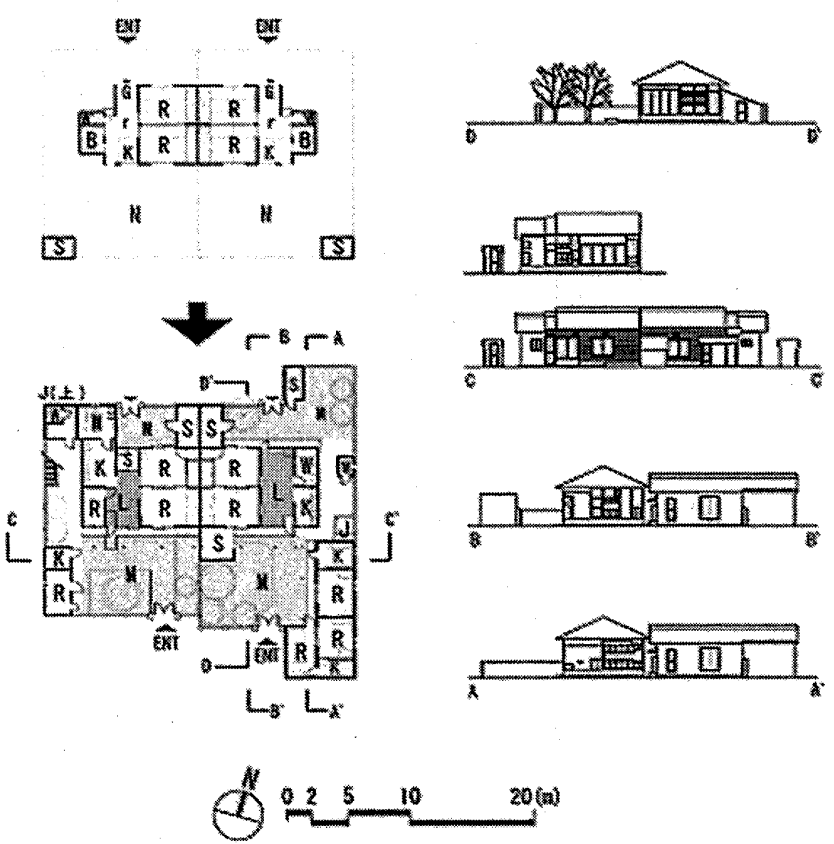

図 11 増改築による内部空間の変化 


\section{5. まとめ}

三浪津鉄道官舎は、京釜線と慶全線の分岐点に 1927 年から 1945 年にかけて駅員の住居として建設された。石垣で築いた敷地に設け られた官舎は、建設当時、北側に出入口、南側に庭を持つ二戸一型 であった。二つの鉄道官舎の変容は、1970 年代初期に行われた払下 げ以後本格的に始まった。

本稿で明らかにしたのは以下のような諸点である。

(1) 韓国では基本的に南入口を重視しているため、立地的な理由か ら変更を行っていない 5 户を除いた 29 戸が出入口の位置の変更を 行っている。出入口の位置の変更は、居住空間の動線を変更させ、 内部空間の大きな変化につながっている。

(2) その中で最も目立つ変化は庭のマダンへの転用である。34 戸の 内、出入口の位置の変化を行ってない官舎を含めた 7 戸を除いた 27 戸についてマダンへの転用が確認された。マダンへの転用によ り官舎本棟の南面に玄関とリビングが設けられ、道路一玄関一廊 下一各室一庭から道路一大門ーマダンーリビングー各室へと動線 軸の変化が起きている。

(3) 16 戸に齐する詳細調查で、14 戸でリビング（コシル）の設置が 確認できた。リビングは元廊下の部分を改造し、台所の位置変更 や部屋の改造によって空間を確保している。内部空間の動線の集 結・分散の起点となり、各室と直接面している。夏には食事や睡 眠空間として使われる大庁の機能も持っている。

(4) 所有者が異なる二戸一型の住宅が構造体を共有しているため、 撤去による新築が難しく、用途や位直変更による改築、増築を中 心とした変化が一般的である。南側に部屋と居閒、北側に収納空 間を拡張する例が多い。そして各室の機能が新たに付与され、そ れに伴う形態の変化が起きている。

(5) 主屋の内部空間の拡張、別棟の増築によって官舎の形態は大き く変わっている。内部空間はリビングの出現、台所とトイレの位 置変更、そして南側への部屋拡張、北側への付属室の拡張などが 行われ、別棟は東西の道路側に賃閒や家族部屋として増筑されて いる。元出入口の北側の門は勝手口として使われている。

(6) 一方、襖、押入、そして天井の高い構造体は換気、通気を考慮 した設計により、現在も変化が起こらず、その形態や機能を残し、 数多くの住居で使用されている。 本稿は鉄道官舎の空間変容を中心としているが、三浪津邑におけ る居住空間の変容について考察する重要な材料を得たと考える。同 じく三浪津鉄道町を構成している駅前商店街の町屋を対象とした空 間変容に関する分析ついては別稿としたい。

\section{参考文献}

1）ハウジング・スタディ・グループ『椲国・現代・居住学』,精興社, 1990 年 2）朝鮮総督府鉄道局『朝鮮鉄道線路案内』朝鮮総督府鉄道局出版部、明治 44

3）密陽誌編筫委員会『密陽誌』密陽文化院

4）密陽市史編纂委員会 『密陽市史』 慶尚南道 密陽市

5）三浪津地名変遷史編纂委員会『三浪津地名変遷史』慶尚南道 密陽市

6) 朝鮮建築会 『朝鮮と建築』第 $1 \sim 20$ 巻 朝鮮建築会 1918 年一1941 年

7）孫祜睦『日本統治下朝鮮都市計画史研究』柏書房 2004 年 12 月

8）孫禎睦『韓国都市変化過程研究』耕文社 2000 年 6 月

9）李賢姫「「韓国における日式住宅の変遷と影響に関する研究」熯陽大、1993

10)朴重信「日本植民地期における日本人移住漁村の形成とその変容に関する 研究小京都大学博士論文、2005 年 3 月

11）朴 重信・布野修司「日本植民地期における日本人移住漁村の形成に関する 研究小、日本建築学会計画系論文集 第 577 号 p 105-110 2004 年 3 月

12）朴 重信・金 泰永・布野修司「韓国・九龍浦の日本人漁村の居住空間構成
とその変容、日本建築学会計画系論文集 第 595 号 p 95-100 2005 年 9 月 13）朴 重信・金 泰永・李 勲・布野修司「韓国・外羅老島の日本人移住漁村 の居住空間構成とその変容」、日本建筑学会計画系論文集 第 595 号 $\mathrm{p} 101-$ 1062005 年 9 月

14）Chae Gi-Byung，Kim TaiYoung、「鉄道建設における近代的都市構造の形成 に関する研究」大韓建築学会学術発表論文集第 17 巻 2 号 p 607-614、 1997. 10

15) Sim WooGab、Kang SangHoon、Yeo SangJin [曰帝強占期におけるアパート建 築に関する研究」大韓建築学会計画系論文集 第 18 巻 9 号 159-168、2002.9 16）Ju U-IL、Kim SangHo、 Lee SangJung「近代化の過程で建立された晋州鉄道 官舎の平面類型に関する研究」大韓建築学会計画系論文集 第 14 巻 8 号 155162、1998. 8

17）Kim SuYoung、Park YoungHwan「解放以前における鉄道官舎の平面特性に関 する研究」大韓建築学会学術発表論文集第 20 卷 1 号 p 313-316、2000.4 18）Ahn SungHo「「帝強占期における官舎の住居史的な意味に関する研究」大韓 建築学会計画棌論文集 第 17 巻 11 号, 2001.11

注

注 1 日本植民地期における韓国の日本人に上って形成された鉄道町の形成と変 容に関する研究は「鉄道町の形成と韓国にお晫る都市化小「日本住文化と韓 国住文化」という二つを基軸とする文化変容の研究である。本研究が詨象と するのは比較的に大きい変化の少ない中小都市である三浪津邑、慶州市、安 洞市、倭館、釜山市九浦など、鉄道駅周辺の町および鉄道官舎である。

注 2 文献 20

注 3 日本植民地期に、日本人又住日本人から教育を受けた韓国人によって韓国 に建てられた日本式の間取りを持つ住宅のことをいう（文献1）

注 4 文献 9

注5 文献 14

注6 文献 16

注 7 文献 17

注 8 文献 2

注 9 文献 6

注 10 京城（現ソウル）と釜山間の国鉄、1905 年 1 月 1 日開通。韓国交通の大 動脈と呼ばれるほど最も重要な役割を果たしている。

注 11 馬山と三浪津間を国鉄、1906 年開通された軍事用臨時線路。慶全線の敷 設によって三浪津は京釜線と慶全線の分岐点となりその指名度が高まってき

注 12 調查参加者 趙 聖民、磯部 孝文、角 真央

注 13 調查参加者 趙 聖民、李 昌業

注 14 調查参加者 趙 聖民、朴 重信

注 15 調查参加者 趙 聖民、朴 重信、金 泰永、青州大学校 建築学科

注 16 韓半島における交通手段の画期的な変化は 1899 年 9 月 18 日の京仁線の敷 設が始まりである。その京仁線の敷設に続き 1942 年 4 月 1 日の中央線の敷設 まで 11 本の国鉄と数多くの私鉄が敷設され、各鉄道駅を中心に近代化された 鉄道町が形成された。

注17 豊臣秀吉の朝鮮出兵により行われた 1592 年から 1598 年の 6 年間に亘る侵 略戦争。一次侵略は壬辰㑕乱、2 次侵略は丁西再乱（日本では文禄慶長の役 中国では萬暦の役）と呼ばれている。

注 18 釜山を占領した豊臣軍は三路（彦陽（蔚山）、金海、密陽）に分か扏、彦 陽と金海を突破した後、密陽を三面攻撃し、天然要塞である三浪津の鹊院關 は陷落した。

注 19 韓半島の南北を走っている太白山脈と小白山脈の南側に位置している地 域で、慶尚南道、慶尚北道、釜山広域市、蔚山広域市、大邱広域市の総称で ある。

注 20 文献 3 、文献 4 、文献 5

注 21 文献 20

注22 仏教教派の一つ。1916 年韓国全羅北道で創立され仏教の現代化、生活化、

大衆化を主張する。信仰の対象が仏像ではなく法身佛の一円相で、1946 年に 円仏教と名付けられた。

注23マダンの一種。裏マダンの意味で建物裏の日陰がある比較的に狭い空間の ことで、一般的にジャンドックを置いたり、野菜などを日陰で干す空間とし て使われている。

注 24 オンドルが冬のためのものであるとマルは夏のためのものである。マルは 日本の縁側にあたる空間で、形熊や場所によってヌマル、テッマル、ゴルマ ル、ノルマル、大庁マルなど様々な名称を持っている。その中で大庁マルは 部屋と部屋の間に位置する最も広いマルで、厚い夏場の食事や作業スペース として使われ、プライバシー度の最も高いアンバンへの進入をコントロール する機能を持っている。

注 25 味噌、清物などを清ける容器(ジャンドク)を置く台のこと、日隆があると ころに設けるが、三浪津鉄道官舎の場合は敷地面積の制限により別棟の屋上 に設けられているのも多数ある。

注26 倉庫の一種、排泄物や生ごみで肥料を作るところを言う。

注 27 『朝鮮と建築』1940年第 3 号 $\mathrm{p} 26-31$ 、朝鮮半島の気候に適灾する設诺の研究より 引用

注28 夫婦部屋のことで面積や位置とは関わらないが、普段南側のリビングと台 所と隣接している。両親と同居している場合は両親部屋がアンバンとなる。 注29 大きい部屋と言う意味で、アンバンの別称。

(2006年 9 月 20 日原稿受理, 2007 年 1 月 5 日採用決定 